\title{
Online journalism at USP
}

The universities of the South Pacific and Papua New Guinea have played pioneering roles in the development of media education resources in the South Pacific. One student training newspaper was the first online publication in the region and another, Wansolwara, was the first online newspaper in Fiji.

\section{By DAVID ROBIE}

IN MARCH 1996, I floated the idea of introducing an electronic publishing course at the institution where I then taught, the University of Papua New Guinea. The idea would be to teach Pacific journalists about the design of Internet websites and how to go about publishing on the Net. At the time, local editors were sceptical about the value of such a course.

Within a month or so we had our own training newspaper, Uni Tavur, on the Web with an online edition, hosted on the Australian Centre for Independent Journalism website at the University of Technology Sydney. This was the first newspaper online in the Pacific.

By August, the fastest growing newspaper in the South Pacific, The National in Port Moresby (owned by the Rimbunan Hijau group of Malaysia), had developed the first daily newspaper website online in the region. Its longestablished rival, the PNG Post-Courier, followed with a classified advertising website linked to the News Ltd advertising website in Australia.

Finally, the Post-Courier also introduced a news website in December 1996. This meant a 100 per cent web presence for Papua New Guinea's national daily newspapers. Following this, the national news weekly, The Independent (owned by the nation's churches - 1998), EM TV (1997) and NauFM (1997), added websites.

News media organisation websites have been slow to take off in Fiji, although the sister radio station of NauFM, FM96 (Fiji Communications Ltd), 


\section{DAVID ROBIE}

has established a popular website, and the news magazine Pacific Islands Monthly (1998) has a site which is mainly a teaser to the purchase of subscriptions.

\section{Internet for Journalism Education in the Pacific:}

The University of Papua New Guinea pioneered journalism education on the Internet in the Pacific region in 1996. At a time when UPNG was still awaiting to go online, a partnership with the University of Technology Sydney's Department of Journalism and Social Analysis meant that the UTS Online Journalist <http://138.25.138.94/acij/> website hosted UPNG's initial efforts. During that year, the training newspaper Uni Tavur went online (designed by a Masters journalism student at UTS), a South Pacific Centre for Communication and Information in Development (SPCenCIID) home page was designed, and Pacific Journalism Review <http://www.asiapac.org.fj/PJR/> and Pacific Media Watch <http://www.pactok.net.au/docs/pmw/> (a partnership with UTS) established home pages.

The Papua Niugini Nius <http://www.pactok.net.au/docs/nius/> email listserve service and website were also created in 1996 in partnership with Pactok Communications, a low cost Asia-Pacific regional email and website cooperative with partners in Cambodia and Malaysia as well as South Pacific states.

The following year, 1997, the UPNG Journalism Studies programme integrated its UTS websites into its journalism production courses and established a redesigned Journalism Studies <http://www.journ.upng.ac.pg/> website at UPNG in October. This included a directory to other PNG sites and an online news service. Under funding from the AusAID Pacific Journalism Training Project, UPNG hosted an "Editing on the Net" course for local journalists in Papua New Guinea.

By March 1998, the pivotal centre of Internet initiatives in journalism education moved from UPNG to the University of Hawai' $i$ and the University of the South Pacific's main Laucala campus in Fiji. In Hawai'i, it took just over a year for Pacific Islands Report <http://pidp.ewc.hawaii.edu/pireport/> to become a key regional news source with around 15 stories a day.

A collaborative project of the Hawai' i's East-West Center's Pacific Islands Development Program and the Center for Pacific Islands Studies at the University of Hawai'i it aims, according to editor Al Hulsen, to increase public knowledge and understanding of the Pacific. Three journalism students are involved in the project.

108 PACIFIC JOURNALISM REVIEW 5:1 1999 


\section{ONLINE}

At the University of the South Pacific <http://www.usp.ac.fj/>, Internet research has been taught since July 1998 in a final year course, JN302 Journalism Research, with five Macintosh computers in the student journalism newsroom having free Internet access for students. Internet publishing and design is being taught along with print journalism in a second year course, JN201 Print and Online Journalism.

\section{Pacific Internet resources:}

In April 1998, the USP Journalism programme launched Pacific Journalism Online <http://www.usp.ac.fj/journ/>, the region's first extensive Internet journalism training tool and research resource. In August, UNESCO awarded a F\$5000 grant to USP Journalism to help develop the project. Equipment was purchased and a Journalism graduate was employed part-time to upload files for the website, including the training newspaper Wansolwara Online subsite. This role has now been taken over by Journalism students as they become trained in Internet publishing.

The website includes the following resources:

News Extra! <http://www.usp.ac.fj/journ/docs/news.html>: A news index which points to current news about the University or media and programme issues.

Café Pacific <http://www.asiapac.org.fj/cafepacific/>: A link to Journalism Coordinator David Robie's own independent website in Fiji, USA and Australia.

Cyber-Times <http://www.cyber-times.org/>: An international electronic training newspaper at City University, Hongkong, which includes work by USP journalism students.

Fiji Web Directory <http://www.internettiji.com/>: Link to Fiji Government and other sites.

Hotlinks <http://www.usp.ac.fj/journ/docs/hotlinks.html>: Quick directory to other Pacific media websites.

Media Ethics <http://www.usp.ac.fj/journ/docs/ethics.html>: Journalism ethical codes around the South Pacific and in the world.

Newslink <http://www.newslink.org >: American Journalism Review directory to the world's media.

Pacific Journalism Review <http://www.asiapac.org.fj/PJR/>: Independent regional media analysis.

Pacific Media Watch <http://www.pactok.net.au/docs/pmw/>: Independent regional media monitoring on media freedom, ownership and ethical issues.

Pasifik Nius <http://www.usp.ac.fj/journ/nius/index.html>: A daily email news 


\section{DAVID ROBIE}

digest produced by Journalism USP which is posted on a website. It has a twoyear archive.

Staff profiles <http://www.usp.ac.fj/journ/docs/staft.html>: Notes on course lecturers.

Student Reporting <http://www.usp.ac.fj/journ/docs/student.html>: An innovative section with "meet the journos", columnist Piloksy and individual journalism student webpages.

Talanoa <http://www.usp.ac.fj/journ/docs/talanoa.html>: Feedback from online readers.

Wansolwara <http://www.usp.ac.fj/journ/docs/wansol.html>: Independent University of the South Pacific journalism training newspaper.

\section{Further reading:}

Robie, David (1997), "The hot-wired media in the Pacific", Pacific Journalism Review Online: <http://www.asiapac.org.fj/cafepacific/resources/aspac/hotwire.html>, Port Moresby: November, pp 61-70.

- (1998), "The Internet and the South Pacific: A Development Media Case Study" (forthcoming as a chapter in a book being published by the MacMillan Brown Pacific Centre, Canterbury University, New Zealand).

$\square$ David Robie is Journalism Coordinator at the University of the South Pacific. This was presented as a paper entitled, "The Internet and journalism education in the South Pacific", at the education workshop, Commonwealth Editors' Forum, Penang, Malaysia, on 21-23 October 1998. The paper is online at: http://www.usp.ac.fj/journ/docs/taveta/inter.html 